\title{
Potential Neurologic Manifestations of COVID-19
}

Anna S. Nordvig, MD, Kathryn T. Fong, MD, Joshua Z. Willey, MD, MS, Kiran T. Thakur, MD, Amelia K. Boehme, PhD, MSPH, Wendy S. Vargas, MD, Craig J. Smith, MBChB, MD, MRCP, and Mitchell S.V. Elkind, MD, MS

Correspondence

Dr. Nordvig

as3703@cumc.columbia.edu

Neurology: Clinical Practice April 2021 vol. 11 no. 2 e135-e146 doi:10.1212/CPJ.0000000000000897

\section{Abstract}

\section{Purpose of Review}

Neurologic complications are increasingly recognized in the coronavirus disease 2019 (COVID-19) pandemic. COVID-19 is caused by the novel severe acute respiratory syndrome coronavirus 2 (SARSCoV-2). This coronavirus is related to severe acute respiratory syndrome coronavirus (SARS-CoV) and other human coronavirus-related illnesses that are associated with neurologic symptoms. These symptoms raise the question of a neuroinvasive potential of SARS-CoV-2.

\section{Recent Findings}

Potential neurologic symptoms and syndromes of SARS-CoV-2 include headache, fatigue, dizziness, anosmia, ageusia, anorexia, myalgias, meningoencephalitis, hemorrhage, altered consciousness, Guillain-Barré syndrome, syncope, seizure, and stroke. In addition, we discuss neurologic effects of other coronaviruses, special considerations for management of neurologic patients, and possible long-term neurologic and public health sequelae.

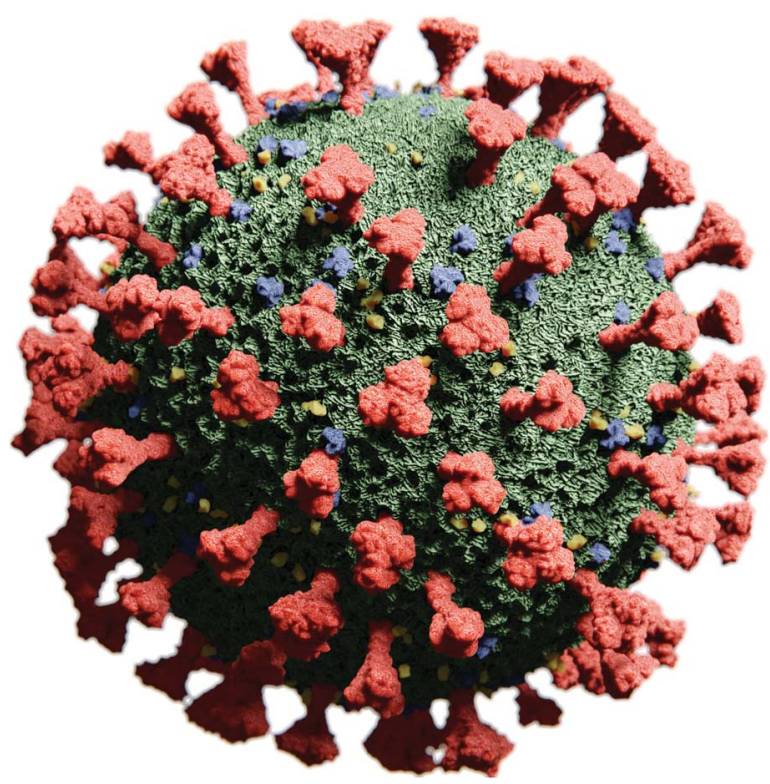

\section{Summary}

As SARS-CoV-2 is projected to infect a large part of the world's population, understanding the potential neurologic implications of COVID-19 will help neurologists and others recognize and intervene in neurologic morbidity during and after the pandemic of 2020.

Coronavirus disease 2019 (COVID-19) is the first coronavirus to cause a global pandemic, ${ }^{1}$ and neurologic problems are increasingly recognized among its complications. The United States now has the highest number of cases worldwide. ${ }^{2}$ Spread of the virus is projected to continue for months. ${ }^{3}$ COVID-19 is caused by the novel severe acute respiratory syndrome coronavirus 2 (SARS-CoV-2), a single-stranded RNA virus that belongs to the sarbecovirus family of betacoronaviruses, together with SARS-CoV. Middle East respiratory syndrome coronavirus (MERS-CoV) belongs to a related family of betacoronaviruses. ${ }^{4}$

\section{MORE ONLINE}

\section{COVID-19 Resources}

For the latest articles, invited commentaries, and blogs from physicians around the world NPub.org/COVID19

Neurologic involvement is documented in SARS-CoV, MERS-CoV, and other coronavirusrelated illnesses. ${ }^{5-8}$ Now as SARS-CoV-2 is projected to infect a large part of the world's population within a short period, ${ }^{3}$ neurologists should be aware of the neurotropic mechanisms and clinical presentations known in other coronaviruses, the potential short-term neurologic

Department of Neurology (ASN, KTF, JZW, KTT, AKB, WSV, MSVE), Vagelos College of Physicians and Surgeons, Columbia University and the New York Presbyterian Hospital, Department of Epidemiology (AKB, MSVE), Mailman School of Public Health, Columbia University, New York, NY; Division of Cardiovascular Sciences (CJS), Lydia Becker Institute of Immunology and Inflammation, University of Manchester; and Manchester Centre for Clinical Neurosciences (CJS), Salford Royal NHS Foundation Trust, Manchester Academic Health Science Centre, Salford, United Kingdom.

Funding information and disclosures are provided at the end of the article. Full disclosure form information provided by the authors is available with the full text of this article at Neurology.org/cp. 
effects of COVID-19, the special considerations for management of neurologic patients during the 2020 crisis, and the possible long-term medical and public health sequelae.

\section{Methods}

A literature review was conducted on PubMed and LitCOVID. Search terms included all combinations of "COVID-19," "SARS-CoV-2," and "coronavirus" with "neurology," "neurologic," and "nervous system." There were 233 articles published before May 8, 2020, that were identified and reviewed for pertinence and validity. The first author reviewed all articles. Other authors provided critical feedback. A formal systematic review, including review of each article by multiple authors, was not pursued, given the exigencies of the pandemic.

\section{Phylogenetic Review of SARS-CoV-2 and Related Coronaviruses}

Coronaviruses are divided into genera by serologic crossreactivity and then further delineated into lineages. SARSCoV-2 is a member of the betacoronavirus (group 2 genus) and sarbecovirus lineage (lineage 2 ). The only other human coronavirus in this lineage is SARS-CoV, which shares $79 \%$ genetic sequence identity with SARS-CoV-2. ${ }^{9}$ Features of other betacoronaviruses are listed in table 1 . Because the genomic sequence identity in conserved replicase domains (ORF 1ab) is less than $90 \%$ between SARS-CoV-2 and all other members of the betacoronavirus family, SARS-CoV-2 has been denoted as a novel betacoronavirus. ${ }^{9}$

\section{Neurologic Involvement in Other Coronaviruses}

Although acute and chronic neurologic diseases in animals have been described in relation to nonhuman strains of coronavirus, ${ }^{10}$ reports of neurologic manifestations from human coronaviruses are infrequent (table 2). ${ }^{11-18}$ There are numerous proposed mechanisms for neurologic involvement by coronaviruses in animals and humans. ${ }^{19}$ Among the 7 strains of human coronavirus known to be pathogenic, 3 strains have been detected in the CNS: 2 strains responsible for up to $30 \%$ of common colds, $\mathrm{HCoV}$ 229E, and $\mathrm{HCoV}-\mathrm{OC} 43,{ }^{6,20}$ as well as SARS-CoV. ${ }^{21}$

The clinical respiratory illness in COVID-19 is similar to SARS, and involvement of other organs may also be similar between the 2 diseases. ${ }^{22}$ The angiotensin-converting enzyme 2 (ACE2) is the portal of entry for both SARS-CoV and SARS-CoV-2. ${ }^{22}$ ACE2 on neurons was implicated as the entry point of CNS infection by SARS-CoV. ${ }^{23}$

In a 2008 mouse study using a selective antibody, ACE2 was found to be widespread on the cardiorespiratory neurons of the brainstem (raphe nuclei, nucleus of the tractus solitarius, and rostral ventrolateral medulla), hypothalamus (paraventricular nucleus), and the subfornical organ, as well as the motor cortex. ${ }^{24-26}$ Human studies using quantitative in vitro

Table 1 Neurologically Notable Coronaviruses in Humans and Animals ${ }^{\mathrm{e}-68}$

\begin{tabular}{|c|c|c|c|c|c|c|c|}
\hline Coronavirus & Host & $\begin{array}{l}\text { Host } \\
\text { entry }\end{array}$ & Reservoir & $\begin{array}{l}\text { Site of } \\
\text { discovery }\end{array}$ & $\begin{array}{l}\text { Major geographic } \\
\text { distribution }\end{array}$ & Systemic features & $\begin{array}{l}\text { Associated neurologic } \\
\text { features }\end{array}$ \\
\hline SARS-CoV & Human & ACE2 & $\begin{array}{l}\text { Bats and } \\
\text { civets }\end{array}$ & China & $\begin{array}{l}\text { China, Taiwan, } \\
\text { Singapore, and Vietnam }\end{array}$ & $\begin{array}{l}\text { Mild to severe } \\
\text { respiratory illness }\end{array}$ & $\begin{array}{l}\text { Encephalopathy, seizure, } \\
\text { stroke, polyneuropathy, } \\
\text { and myopathy }\end{array}$ \\
\hline MERS-CoV ${ }^{\mathrm{e}-69}$ & Human & DPP4 & $\begin{array}{l}\text { Bats and } \\
\text { camels }\end{array}$ & $\begin{array}{l}\text { Saudi } \\
\text { Arabia }\end{array}$ & $\begin{array}{l}\text { Egypt, Oman, Qatar, } \\
\text { and Saudi Arabia }\end{array}$ & $\begin{array}{l}\text { Moderate to severe } \\
\text { respiratory illness }\end{array}$ & $\begin{array}{l}\text { Encephalopathy, ischemic } \\
\text { stroke, and intracerebral } \\
\text { hemorrhage }\end{array}$ \\
\hline HCoV-OC43 & Human & Unknown & $\begin{array}{l}\text { Bats and } \\
\text { rodents }\end{array}$ & & Global & Mild respiratory illness & $\begin{array}{l}\text { ADEM (case report) and } \\
\text { acute encephalitis } \\
\text { (possible) }\end{array}$ \\
\hline HCoV-229E & Human & APN & $\begin{array}{l}\text { Bats and } \\
\text { camelids }\end{array}$ & & Global & Mild respiratory illness & Encephalitis (possible) \\
\hline HCoV-NL63 ${ }^{\mathrm{e}-70}$ & Human & ACE2 & & & Global & Mild respiratory illness & None reported \\
\hline Mouse hepatitis virus & Mouse & & & & & $\begin{array}{l}\text { Severe pneumonitis } \\
\text { and SARS }\end{array}$ & $\begin{array}{l}\text { Acute encephalitis or } \\
\text { chronic demyelinating } \\
\text { disease }^{\mathrm{e}-7}\end{array}$ \\
\hline $\begin{array}{l}\text { Sialodacryoadenitis } \\
\text { coronavirus }\end{array}$ & Rat & & & & & & Neurologic infection ${ }^{\mathrm{e}-71}$ \\
\hline $\begin{array}{l}\text { Hemagglutinating } \\
\text { encephalomyocarditis } \\
\text { virus }\end{array}$ & Pig & & & & & & Neurologic infection ${ }^{\mathrm{e}-71}$ \\
\hline
\end{tabular}

Abbreviations: ACE2 = angiotensin-converting enzyme 2; ADEM = acute disseminated encephalomyelitis; APN = aminopeptidase N; DPP4 = dipeptidyl peptidase 4.

MERS-CoV (50\% identity with SARS-CoV-2). 


\section{Table 2 Neurologic Findings in Case Reports of SARS-CoV, MERS-CoV, and HCoV-OC43}

\begin{tabular}{|c|c|c|c|c|c|}
\hline Demographic & $\begin{array}{l}\text { Clinical } \\
\text { presentation }\end{array}$ & Neurologic presentation & CSF findings & Neurologic clinical studies & $\begin{array}{l}\text { Autopsy } \\
\text { findings }\end{array}$ \\
\hline \multicolumn{6}{|l|}{ SARS-CoV } \\
\hline $\begin{array}{l}\text { 32-y-old woman, } 26 \text { wk } \\
\text { pregnant }^{38}\end{array}$ & $\begin{array}{l}\text { Fever, myalgias, dry cough, } \\
\text { progressed to respiratory and renal } \\
\text { failure, extubated day } 27\end{array}$ & $\begin{array}{l}\text { Generalized tonic-clonic } \\
\text { convulsions on day } 22\end{array}$ & $\begin{array}{l}\text { + SARS-CoV RNA, otherwise } \\
\text { noninflammatory with } 20 \text { RBCs } \\
\text { per } \mathrm{mm}^{3}\end{array}$ & $\begin{array}{l}\text { Normal MRI day } 46 \\
\text { Normal EEG day } 39\end{array}$ & Survived \\
\hline $\begin{array}{l}\text { 59-y-old woman, IgA } \\
\text { nephropathy on peritoneal } \\
\text { dialysis }^{14}\end{array}$ & $\begin{array}{l}\text { Fever, chills, cough, diarrhea, and } \\
\text { respiratory distress }\end{array}$ & $\begin{array}{l}\text { Vomiting and appendicular } \\
\text { twitching on hospital day } 5\end{array}$ & $\begin{array}{l}\text { + SARS-CoV RNA 6,884 copies/mL, }{ }^{a} \\
\text { otherwise noninflammatory }\end{array}$ & $\begin{array}{l}\text { Normal HCT } \\
\text { No MRI or EEG available }\end{array}$ & Outcome not provided \\
\hline $39-y$-old $\operatorname{man}^{18}$ & $\begin{array}{l}\text { Fever, chills, headaches, dizziness, } \\
\text { myalgias, treated with ribavirin/ } \\
\text { steroids for } 1 \text { mo, bacterial } \\
\text { pneumonia, and ARDS }\end{array}$ & $\begin{array}{l}\text { Obscured monocular vision, } \\
\text { dysphoria, delirium, and vomiting } \\
\text { after } 1 \text { mo }\end{array}$ & NA & $\begin{array}{l}\text { CT showed abnormalities } \\
\text { consistent with ischemia or brain } \\
\text { edema on day } 33 \text { and brain } \\
\text { herniation day } 35\end{array}$ & $\begin{array}{l}\text { Viral N protein in glial cells and } \\
\text { neurons. Enveloped viral particles } \\
\text { compatible with coronavirus in } \\
\text { suspended tissue }^{\mathrm{b}}\end{array}$ \\
\hline 51-y-old woman 36 & $\begin{array}{l}\text { Fever, dyspnea, cough, and } \\
\text { diarrhea progressed to multiple } \\
\text { organ failure and intubation }\end{array}$ & $\begin{array}{l}\text { Distal-predominant } 4 \text {-limb } \\
\text { weakness and leg numbness on } \\
\text { day } 21\end{array}$ & NA & EMG polyradiculoneuropathy & Survived \\
\hline 48-y-old woman ${ }^{36}$ & $\begin{array}{l}\text { Fever, dyspnea, and myalgia } \\
\text { progressed to multiple organ } \\
\text { failure and intubation }\end{array}$ & $\begin{array}{l}\text { Distal-predominant 4-limb } \\
\text { weakness and bilateral finger } \\
\text { numbness on day } 24\end{array}$ & $\begin{array}{l}\text { Protein } 46 \text { mg/dL, negative SARS- } \\
\text { CoV }\end{array}$ & $\begin{array}{l}\text { EMG axonopathic sensorimotor } \\
\text { polyneuropathy, recovery by day } \\
92\end{array}$ & Survived \\
\hline 42-y-old woman 36 & $\begin{array}{l}\text { Fever and dyspnea progressed to } \\
\text { multiple organ failure and } \\
\text { intubation }\end{array}$ & $\begin{array}{l}\text { Distal-predominant 4-limb } \\
\text { weakness and left foot numbness } \\
\text { on day } 25\end{array}$ & $\begin{array}{l}\text { Protein } 15 \mathrm{mg} / \mathrm{dL} \text {, } 0 \text { cells, negative } \\
\text { SARS-CoV }\end{array}$ & $\begin{array}{l}\text { CPK 9050; EMG myopathy with } \\
\text { asymmetric sensorimotor } \\
\text { polyneuropathy (axonopathic); } \\
\text { recovery day } 87\end{array}$ & Survived \\
\hline $31-y$-old $\operatorname{man}^{36}$ & Fever, cough, and soft stool & Proximal leg weakness on day 22 & NA & $\begin{array}{l}\text { EMG myopathy, complete recovery } \\
\text { by day } 94\end{array}$ & Survived \\
\hline \multicolumn{6}{|l|}{ MERS-CoV } \\
\hline $\begin{array}{l}\text { 74-y-old man with HTN, DM, } \\
\text { and dyslipidemia }{ }^{\text {e-72 }}\end{array}$ & $\begin{array}{l}\text { Unclear initial presentation; fever, } \\
\text { later had lymphopenia with } \\
\text { critically low absolute CD4 and CD8 } \\
\text { counts }\end{array}$ & Confusion, ataxia, and vomiting & $\begin{array}{l}\text { Noninflammatory with negative } \\
\text { MERS-CoV RT-PCR }\end{array}$ & $\begin{array}{l}\text { MRI multifocal nonenhancing T1 } \\
\text { hypo-, T2 hyperintensities, } \\
\text { restriction, subcortical gray and } \\
\text { white matter }\end{array}$ & No autopsy \\
\hline $\begin{array}{l}\text { 57-y-old man with HTN and } \\
\text { DM }^{\text {e-73 }}\end{array}$ & $\begin{array}{l}\text { Flu-like illness, myocardial } \\
\text { ischemia, pulmonary edema, and } \\
\text { gangrenous toe }\end{array}$ & $\begin{array}{l}\text { Bilateral multifocal anterior } \\
\text { circulation stroke }\end{array}$ & NA & $\begin{array}{l}\text { CTA near occlusion at origin of both } \\
\text { internal carotid arteries, middle } \\
\text { cerebral artery narrowing, and no } \\
\text { vasculitis }\end{array}$ & No autopsy \\
\hline $\begin{array}{l}\text { 45-y-old man with HTN, } \\
\text { chronic kidney disease, and } \\
\text { ischemic heart disease }\end{array}$ & $\begin{array}{l}\text { Fever, respiratory symptoms, } \\
\text { diarrhea, pneumonia, and kidney } \\
\text { injury }\end{array}$ & $\begin{array}{l}\text { After tracheostomy on hospital day } \\
24 \text {, impaired consciousness }\end{array}$ & $\begin{array}{l}\text { Elevated protein, negative MERS- } \\
\text { CoV RT-PCR }\end{array}$ & $\begin{array}{l}\text { MRI confluent T2 hyperintensities } \\
\text { in bilateral white matter and } \\
\text { corticospinal tracts, no } \\
\text { enhancement, or restriction }\end{array}$ & Survived, discharged home day 107 \\
\hline
\end{tabular}


Table 2 Neurologic Findings in Case Reports of SARS-CoV, MERS-CoV, and HCoV-OC43 (continued)

\begin{tabular}{|c|c|c|c|c|c|}
\hline Demographic & $\begin{array}{l}\text { Clinical } \\
\text { presentation }\end{array}$ & Neurologic presentation & CSF findings & Neurologic clinical studies & $\begin{array}{l}\text { Autopsy } \\
\text { findings }\end{array}$ \\
\hline $\begin{array}{l}\text { 42-y-old woman with obesity } \\
\text { and } \mathrm{DM}^{\mathrm{e}-74}\end{array}$ & $\begin{array}{l}\text { ARDS, lymphopenia, leukopenia, } \\
\text { and treated with steroids and } \\
\text { antivirals }\end{array}$ & $\begin{array}{l}\text { Diabetes insipidus, then massive } \\
\text { intraparenchymal hemorrhage } \\
\text { with SAH }\end{array}$ & Unable due to tonsillar herniation & No aneurysm visualized on CTA & No autopsy \\
\hline 34-y-old woman with $\mathrm{DM}^{\mathrm{e}-73}$ & $\begin{array}{l}\text { ARDS, lymphopenia, inflammation, } \\
\text { and DIC }\end{array}$ & Intracranial hemorrhage on day 14 & NA & $\begin{array}{l}\text { Head CT with ICH, massive edema, } \\
\text { and midline shift }\end{array}$ & No autopsy \\
\hline 28-y-old man me-73 $^{2}$ & $\begin{array}{l}\text { Fever, ARDS, and bacterial } \\
\text { pneumonia }\end{array}$ & $\begin{array}{l}\text { Myalgias, then paraparesis/ } \\
\text { paresthesia (critical illness) }\end{array}$ & NA & $\begin{array}{l}\text { EMG: length-dependent axonal } \\
\text { polyneuropathy } \\
\text { Normal spine MRI }\end{array}$ & Survived \\
\hline \multicolumn{6}{|l|}{ HCoV-OC43 } \\
\hline $9 \mathrm{mo}_{75}$ old with acute leukemia ${ }^{\mathrm{e}-}$ & Fever and upper airway symptoms & $\begin{array}{l}\text { Altered consciousness and } \\
\text { myoclonic seizures }\end{array}$ & Negative CSF & $\begin{array}{l}\text { Normal head CT and abnormal } \\
\text { brain MRI }\end{array}$ & $\begin{array}{l}\text { Brain tissue positive for HCoV- } \\
\text { OC43 }\end{array}$ \\
\hline $\begin{array}{l}11 \text { mo old with combined } \\
\text { immunodeficiency }\end{array}$ & Respiratory infection & Encephalitis & NA & & $\begin{array}{l}\text { Brain tissue positive for HCoV- } \\
\text { OC43 }\end{array}$ \\
\hline $15-y-o l d ~ m a n=e-76$ & Upper respiratory symptoms & $\begin{array}{l}\text { Ascending numbness and gait } \\
\text { difficulty } 5 \mathrm{~d} \text { before hospitalization }\end{array}$ & + HCoV-OC43 RNA & $\begin{array}{l}\text { MRI of the brain and spine: acute } \\
\text { disseminated encephalomyelitis }\end{array}$ & Survived \\
\hline
\end{tabular}

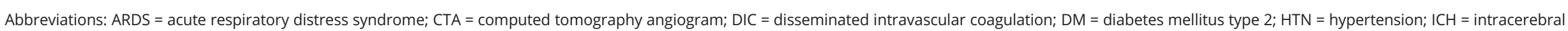
hemorrhage; NA = not available; $S A H$ = subarachnoid hemorrhage.

a SARS-CoV RNA was isolated in both CSF and serum at 6,884 and 6,750 copies $/ \mathrm{mL}$, respectively.

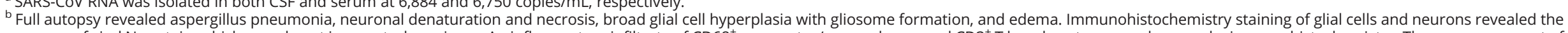

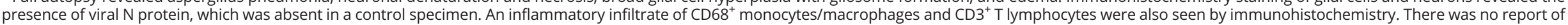

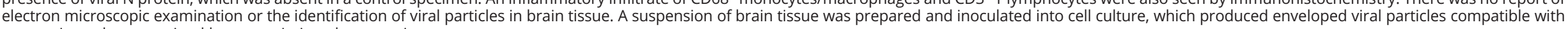
coronavirus when examined by transmission electron microscopy 
autoradiography have shown ACE2 on neurons and glia in the hypothalamus, midbrain, pons, cerebellum, medulla oblongata, and basal ganglia, ${ }^{27}$ although the enzyme's distribution in the human CNS is not as well characterized as in mice. $^{28}$

ACE2 is also found on endothelial cells. ${ }^{29}$ Endothelial involvement in the brain could theoretically also lead to bloodbrain barrier (BBB) disruption, such as that found in hypertension $^{30}$ and a proinflammatory state. ${ }^{31}$

In mouse models, there is immunohistochemical evidence of SARS-CoV and MERS-CoV CNS invasion, especially in the brainstem. ${ }^{32-34}$ In an underpowered human autopsy study, in situ hybridization confirmed the presence of viral RNA of $\mathrm{HCoV}-229 \mathrm{E}$ and HCoV-OC43 strains in brain bank samples of 14 of $39(36 \%)$ patients with multiple sclerosis (MS) and in 7 of 51 (14\%) controls (25 normal controls and 26 patients with other neurologic diseases). ${ }^{6}$

In the pediatric population, $\mathrm{HCoVs}$ have been associated with clinical neurologic disease. In a single-center Chinese study, IgM antibodies to $\mathrm{HCoV}$ were found in the CSF of $12 \%$ of hospitalized children with encephalitis over a 1-month period. ${ }^{17}$ Rare case reports suggest a link to fatal encephalitis and acute disseminated encephalomyelitis (table 2).

The SARS-CoV epidemic in 2003 tallied over 8,000 infections and 700 deaths. Case reports of neurologic illness in SARS-CoV (table 2) include central and peripheral nervous system manifestations-delirium, reduced level of consciousness, ${ }^{14,18}$ seizures, ${ }^{12,18}$ stroke, myopathy, ${ }^{1,35}$ neuropathy, ${ }^{36}$ and striated muscle vasculitis. ${ }^{37}$

MERS-CoV has not been isolated from CSF or postmortem brain specimens among approximately 2,500 laboratoryconfirmed cases, but there are 6 patients described with neurologic illness following an intensive care unit (ICU) course (table 2).

Another autopsy study from 8 confirmed SARS cases found evidence of SARS-CoV genetic material in the brain by in situ hybridization, electron microscopy, and RT-PCR ${ }^{38}$ The signals were confined to the cytoplasm of numerous neurons in the hypothalamus and cortex. Edema and scattered red degeneration of the neurons were present in the brains of 6 of the 8 confirmed cases of SARS. SARS viral sequences and pathologic changes were not present in the brains of unconfirmed cases or 6 age-matched head trauma control cases. The report does not specify if any of the 8 SARS cases manifested neurologic symptoms during their acute illness. Importantly, edema and acidophilic neuronal degeneration are nonspecific markers of acute neuronal injury ${ }^{39}$ - there was no reported evidence of direct pathologic effects of SARS-CoV. This study, therefore, does not confirm whether the genomic sequences detected are indicative of direct viral invasion, virus-related brain injury, or an incidental secondary phenomenon.
Weaknesses of these studies include limited or inconsistent information about autopsy, inconsistent neuroimaging evidence of cerebral injury, comorbid conditions, and morbidities of intensive care treatment that are known to cause neurologic events. Many questions arise about the role of immunosuppression in these cases: did steroids alone or in combination with SARS-associated lymphopenia facilitate neuroinvasion? Was the patient with autoimmune history receiving immunosuppressive treatment? In addition, endstage renal disease requiring dialysis may have contributed to an underlying immunosuppressed state.

\section{Mechanisms of CNS Injury by Coronaviruses and Other Infections and Implications for SARS-CoV-2}

HCoVs have proven capable of using at least 3 pathways for direct viral entry into the $\mathrm{CNS}^{15}$ - some of these may be relevant to SARS-CoV-2 (table 3).

First, direct inoculation of the olfactory bulb through the cribriform plate may be one mechanism for the introduction of the virus into the CNS. ${ }^{32, \mathrm{e}-8}$ Direct intranasal inoculation of SARS-CoV in mice induced widespread SARS-CoV neuronal infection in areas with first- or second-order connections with the olfactory bulb within 7 days. After inoculation, transneuronal spread was the likely mechanism for further viral infection. ${ }^{32}$ In a 1990 study, ablation of the olfactory bulb prevented the spread of the mouse hepatitis virus type 3 coronavirus (MHV) on nasal inoculation. ${ }^{40}$ Moreover, low doses of MERS-CoV introduced intranasally in mice resulted only in CNS infection, and spared other organs in mice, providing indirect evidence for neurotropism. ${ }^{34}$

In COVID-19, small studies are showing high rates of selfreported anosmia, and also ageusia (perhaps due to involvement of gustatory receptors), often without rhinorrhea or nasal congestion..$^{\mathrm{e}-1-\mathrm{e}-3}$ Olfactory and gustatory dysfunction may be independent and persistent symptoms even as they are highly correlated in incidence (table 4 ). Whether the presence of these symptoms indicates transnasal spread and portends a mechanism that causes greater neurologic disease requires further study.

Second, in pigs and birds, after infection of peripheral nerve terminals through oronasal inoculation, CNS invasion may also occur by retrograde synaptic transmission through sensory nerves and ganglia. Trans-synaptic transfer has been documented in other coronavirus animal models such as swine hemagglutinating encephalomyelitis virus (where eventual brainstem infection was first detected in the trigeminal and vagal sensory nuclei) and avian bronchitis virus. $^{\mathrm{e}-4}$

In a 2015 study of MHV in mice, BBB invasion by coronaviruses correlated with virus-induced disruption of tight junctions on brain microvascular endothelial cells. This led to BBB dysfunction and enhanced permeability. ${ }^{\mathrm{e}-5}$ When MHV 
Table 3 Potential Mechanisms for Neurologic Injury in COVID-19

\begin{tabular}{l}
\hline Routes of direct CNS viral invasion ${ }^{32, e-77}$ \\
\hline $\begin{array}{l}\text { Peripheral nerve infection (e.g., direct intranasal inoculation, } \\
\text { mechanoreceptors and } \\
\text { chemoreceptors in the lung and lower respiratory airways, } \\
\text { perhaps oropharyngeal) }\end{array}$
\end{tabular}

Olfactory receptor neuron infection through direct inoculation

Retrograde trans-synaptic transmission after infection of the peripheral nerve

Direct CNS neuronal entry

BBB disruption and infection of microvascular endothelial cells following viremia

Infection of circulating leukocytes ${ }^{38}$ that traffic the virus across the BBB (Trojan horse entry)

Indirect mechanisms for neuronal injury

Systemic inflammation (includes hypercoagulable state and cytokine storm)

Endothelial invasion, injury, and thrombosis

Hypoxic-anoxic brain injury after cardiorespiratory failure

CNS demyelination

Abbreviation: BBB = blood-brain barrier.

is directly inoculated into the CNS, proinflammatory cytokines and chemokines surge. Neutrophils, natural killer cells, and monocyte/macrophages rapidly migrate to the CNS, secreting matrix metalloproteinases to permeate the BBB. Virus-specific T cells infiltrate the CNS; oligodendroglia are primary targets of infection. Importantly, the virus becomes undetectable in the CSF 2 weeks postinfection, but persists mainly in white matter tracts. As a result of this largely immune-mediated response, animals develop demyelinating lesions within the brain and spinal cord that are associated with clinical manifestations, including awkward gait and hindlimb paralysis. ${ }^{\mathrm{e}-6-\mathrm{e}-8}$ Although SARS-CoV-2 has not yet been identified in CNS endothelium, viral particles were found on electron microscopy in renal endothelial cells of 1 patient with a remote history of renal transplant; the 2 others in the series had systemic endotheliitis but no viral particles. $^{\mathrm{e}-9}$

Acute infections may be a trigger for stroke due to increased inflammation and consequent thrombosis. ${ }^{\mathrm{e}-10-\mathrm{e}-12}$ In analyses from the Cardiovascular Health Study (CHS) and the Atherosclerosis Risk in Communities study, recent hospitalization for infection was associated with an increased risk of stroke. ${ }^{\mathrm{e}-13}$ In CHS, among 669 participants who experienced a stroke, the risk of stroke increased following hospitalization for infection within the previous 30 days (odds ratio $7.3,95 \%$ confidence interval 1.9-40.9). A populationbased cohort study from Denmark showed that $\sim 80 \%$ of cardiovascular events after exposure to bacteremia occurred during the index hospitalization, with the risk of stroke highest in the first 3-15 days postinfection. ${ }^{\mathrm{e}-14}$ Even influenza and minor respiratory and urinary tract infections are associated with increased stroke risk, and vaccinations may help prevent stroke. ${ }^{\mathrm{e}-12, \mathrm{e}-15}$ A Cochrane review of 8 randomized controlled trials (12,029 participants) provides evidence that influenza vaccination decreased cardiovascular outcomes, and a case series study found that the risk of stroke was increased after respiratory tract infection and was reduced after vaccination against influenza, pneumococcal infection, and tetanus. ${ }^{\mathrm{e}-16}$ Research with administrative data has also identified sepsis as a stroke trigger, although the absolute risk is low. ${ }^{\mathrm{e}-12}$

Some critically ill patients with COVID-19 experience a systemic inflammatory response syndrome (cytokine storm) that may lead to endothelial dysfunction ${ }^{\mathrm{e}-17}-$ a known risk factor for thromboembolic events. ${ }^{\mathrm{e}-18}$ Many systemic markers of proinflammatory activation are elevated, including multiple cytokines. For example, peripheral tumor necrosis factor- $\alpha$, a key upstream mediator of the systemic inflammatory response, and interleukin-6 (IL-6), a key driver of the acute-phase response, are higher in more severe COVID-19. ${ }^{22, \mathrm{e}-19}$

IL-6 is critically involved in thromboinflammatory activation, and elevated concentrations may therefore drive a prothrombotic state. Perturbations to the thrombosiscoagulation pathways have also been reported. Disruption to both anticoagulant (e.g., reduced antithrombin and elevated lupus anticoagulant) and procoagulant/thrombotic (increased fibrinogen, D-dimer, and increased prothrombin time) pathways is reminiscent of disseminated intravascular coagulation (table 4). ${ }^{\mathrm{e}-20}$ In a case series of 5 COVID-19 skin and lung biopsies, thrombotic microvascular injury was associated with extensive complement activation. $^{\mathrm{e}-21}$

There have been several reports of acute myopericarditis and other cardiac complications with SARS-CoV-2 $2^{\mathrm{e}-22}$ and SARS$\mathrm{CoV},{ }^{\mathrm{e}-23}$ which, combined with hypercoagulability, could also lead to stroke as a consequence of cardiac arrhythmia and dysfunction causing cardiac embolism.

In summary, neurologic effects of coronaviruses including SARS-CoV-2 may be triggered by direct cytopathic effects of the virus, secondary effects of severe pulmonary infection, the systemic inflammatory response (cytokine storm), or a combination of these.

\section{Clinical Neurologic Findings in COVID-19}

Reports of early and mild neurologic symptoms of COVID19 differ in both symptom classification and incidence despite most of them being reported from hospitalized cohorts; the most commonly reported symptoms are headache, mild confusion, dizziness, myalgias, fatigue, anorexia, anosmia, and ageusia (table 4). Many of these reported symptoms are 
Table 4 Neurologic Findings in Case Reports and Case Series of Systemic SARS-CoV-2 Infection (COVID-19)

\begin{tabular}{|c|c|c|c|c|}
\hline Possible neurologic symptom & $\mathrm{N}$ & $\%$ of cohort & Comment & Region \\
\hline \multicolumn{5}{|l|}{ Early and mild neurologic symptoms } \\
\hline \multirow[t]{5}{*}{ Hyposmia/anosmia } & 357 & 85.6 & $\begin{array}{l}\text { Mild-to-moderate patients, questionnaire response, } \\
\sim 10 \text { d postonset }\end{array}$ & Western Europe $\mathrm{e}^{\mathrm{e}-2}$ \\
\hline & 44 & 61.1 & $25 \%$ hospitalized, $75 \%$ outpatients & Italye-78 \\
\hline & 11 & 5.1 & Hospitalized patients & China ${ }^{\mathrm{e}-27}$ \\
\hline & 1 & $\sim 40$-y-old n & $\begin{array}{l}\text { h anosmia, cough, headache, and without ageusia; MRI: } \\
\text { inflammation of olfactory clefts }\end{array}$ & France ${ }^{\mathrm{e}-79}$ \\
\hline & 12 & 5.6 & Hospitalized patients & China ${ }^{\mathrm{e}-27}$ \\
\hline \multirow[t]{2}{*}{ Hypogeusia/ageusia } & 342 & 88.8 & Mild-to-moderate patients, questionnaire response & Western Europe $\mathrm{e}^{\mathrm{e}-2}$ \\
\hline & 39 & 54.2 & $25 \%$ hospitalized, $75 \%$ outpatients & Italye ${ }^{\mathrm{e}-78}$ \\
\hline \multirow[t]{4}{*}{ Fatigue/malaise/asthenia } & 418 & 38.0 & Hospitalized patients & China $a^{\mathrm{e}-80}$ \\
\hline & 69 & 26.3 & Hospitalized, mainly mildly ill patients & China $a^{\mathrm{e}-81}$ \\
\hline & 48 & 66.7 & $25 \%$ hospitalized, $75 \%$ outpatients, $\sim 19 \mathrm{~d}$ postonset & Italy ${ }^{\mathrm{e}-78}$ \\
\hline & 18 & 34.6 & Critically ill hospitalized patients & China $\mathrm{e}^{\mathrm{e}-82}$ \\
\hline \multirow[t]{7}{*}{ Headache } & 150 & 13.6 & Hospitalized patients & China ${ }^{\mathrm{e}-80}$ \\
\hline & 30 & 41.7 & $25 \%$ hospitalized, $75 \%$ outpatients, $\sim 19 \mathrm{~d}$ postonset & Italy ${ }^{\mathrm{e}-78}$ \\
\hline & 28 & 13.1 & Hospitalized patients & China $^{\mathrm{e}-27}$ \\
\hline & 17 & 6.5 & Hospitalized, mainly mildly ill patients & China $^{\mathrm{e}-81}$ \\
\hline & 9 & 6.5 & Hospitalized patients & China ${ }^{\mathrm{e}-83}$ \\
\hline & 3 & 7.9 & Hospitalized patients & China ${ }^{22}$ \\
\hline & 3 & 5.8 & Critically ill hospitalized patients & China $^{\mathrm{e}-82}$ \\
\hline Anorexia & 55 & 39.9 & Hospitalized patients & China $^{\mathrm{e}-83, \mathrm{a}}$ \\
\hline \multirow[t]{2}{*}{ Dizziness } & 36 & 16.8 & Hospitalized patients & China $^{\mathrm{e}-27}$ \\
\hline & 13 & 9.4 & Hospitalized patients & China $a^{\mathrm{e}-83}$ \\
\hline \multirow[t]{4}{*}{ Myalgia + fatigue + arthralgia } & 48 & 34.8 & Hospitalized patients & China $^{\mathrm{e}-83}$ \\
\hline & 6 & 11.5 & Critically ill hospitalized patients & China ${ }^{\mathrm{e}-82}$ \\
\hline & 18 & 43.9 & Hospitalized patients & China $^{22}$ \\
\hline & 164 & 14.9 & Hospitalized patients & China $\mathrm{e}^{\mathrm{e}-80}$ \\
\hline Nerve pain & 5 & 2.3 & Hospitalized patients & China $a^{\mathrm{e}-27}$ \\
\hline
\end{tabular}

More severe neurologic symptoms (partial table, see appendix e-1)

\begin{tabular}{|c|c|c|c|c|}
\hline Post-ARDS encephalopathy & 26 & 65.0 & $\begin{array}{l}\text { MRI: } 11 / 13 \text { bifrontotemporal perfusion abnormalities, } 8 / \\
13 \text { leptomeningeal enhancement; CSF: } 2 / 7 \text { OCBs, } 1 / 7 \\
\text { elevated immunoglobulins and protein, no SARS-CoV-2; } \\
\text { EEG: only } 1 / 8 \text { diffuse bifrontal slowing }\end{array}$ & France $^{\mathrm{e}-84}$ \\
\hline Impaired consciousness & 16 & 7.5 & Hospitalized patients & China $a^{\mathrm{e}-27}$ \\
\hline Muscle injury & 23 & 10.7 & Hospitalized patients & China $a^{\mathrm{e}-27}$ \\
\hline \multirow[t]{3}{*}{ Stroke } & 13 & 5.9 & $\begin{array}{l}3 \text { small vessel occlusions, } 5 \text { large vessel stenosis, and } 3 \\
\text { cardioembolic, } 1 \text { cerebral venous thrombosis, } 1 \\
\text { hemorrhage (onset } \sim 10 \mathrm{~d} \text { ) }\end{array}$ & China ${ }^{\mathrm{e}-28}$ \\
\hline & 6 & 2.8 & $\begin{array}{l}\text { Hospitalized patients ( } 5.7 \% \text { in severe infections vs } 0.8 \% \\
\text { in nonsevere infections) }\end{array}$ & China ${ }^{\mathrm{e}-27}$ \\
\hline & 3 & 3.7 & Arterial ischemic strokes (cumulative incidence) & The Netherlands $\mathrm{s}^{\mathrm{e}-4 \mathrm{t}}$ \\
\hline
\end{tabular}


Table 4 Neurologic Findings in Case Reports and Case Series of Systemic SARS-CoV-2 Infection (COVID-19) (continued)

\begin{tabular}{|c|c|c|c|}
\hline \multirow[t]{2}{*}{ Possible neurologic symptom } & $\mathrm{N}$ & $\%$ of cohort & Region \\
\hline & 6 & $\begin{array}{l}\text { 53-85 y old, 6/6 large vessel occlusions ( } 3 \text { multiterritory infarcts, } 2 \text { concurrent } \\
\text { venous thromboses, } 2 \text { ischemic strokes despite therapeutic anticoagulation), D- } \\
\text { dimer levels } \geq 1,000 \mu \mathrm{g} / \mathrm{L} \text { (onset } 0-24 \mathrm{~d} \text { ) }\end{array}$ & United Kingdom ${ }^{\mathrm{e}-85}$ \\
\hline & 5 & $\begin{array}{l}\text { 33-49y old, 5/5 large vessel occlusions, } 3 / 5 \text { with elevated fibrinogen, D-dimer, and } \\
\text { ferritin (onset } 0 \text { y) }\end{array}$ & New York ${ }^{\mathrm{e}-86}$ \\
\hline & 4 & $\begin{array}{l}\text { 73-88 y old, } 1 \text { embolic, } 2 \text { large vessel stenosis, } 1 \text { internal carotid occlusion (onset } \\
0-2 \mathrm{~d} \text { ) }\end{array}$ & New York ${ }^{\mathrm{e}-87}$ \\
\hline & 4 & $\begin{array}{l}\text { 45-77 y old, } 2 \text { suspected large vessel stenosis and } 2 \text { small vessel occlusions on } \\
\text { MRI, 3/4 elevated D-dimer, 2/4 elevated CRP, } 1 / 4 \text { elevated ferritin, none critically ill } \\
\text { (onset } 1-4 \text { d) }\end{array}$ & Turkey $^{\mathrm{e}-88}$ \\
\hline & 3 & 65-70 y old, multiple bilateral cerebral infarcts and ARDS (onset 10-33 d) & China $^{\mathrm{e}-89}$ \\
\hline \multirow[t]{4}{*}{$\begin{array}{l}\text { Guillain-Barré syndrome (partial list, } \\
\text { continued in appendix e-1) }\end{array}$} & 5 & $\begin{array}{c}\text { 23-77 y old, EMG: } 3 / 5 \text { axonal, 2/5 demyelinating; } 2 / 5 \text { antiganglioside Ab, CSF: 3/5 } \\
\text { albuminocytologic dissociation, no SARS-CoV-2; MRI: } 2 \text { caudal and } 1 \text { facial nerve } \\
\text { enhancement (onset 5-10 d) }\end{array}$ & Italy \\
\hline & 1 & $\begin{array}{l}\text { 61-y-old woman, EMG: demyelinating neuropathy; CSF: protein } 124 \mathrm{mg} / \mathrm{dL}, 5 \\
\text { cells/ } \mathrm{LL} \text { (presenting symptom, } 4 \mathrm{~d} \text { after visiting endemic region) }\end{array}$ & China $^{\mathrm{e}-91}$ \\
\hline & 1 & $\begin{array}{l}\text { 65-y-old man, EMG: motor-sensory axonal neuropathy; MRI: negative (onset } \sim 2+ \\
\quad \text { wk) }\end{array}$ & $\operatorname{Iran}^{\mathrm{e}-92}$ \\
\hline & 1 & $\begin{array}{l}\text { 71-y-old man, EMG: acute polyradiculoneuritis with prominent demyelination; } \\
\text { CSF: protein } 54 \mathrm{mg} / \mathrm{dL}, 9 \text { cells/ } \mu \mathrm{L} \text {, no SARS-CoV-2 (onset day 8) }\end{array}$ & Italy ${ }^{\mathrm{e}-93}$ \\
\hline \multicolumn{4}{|c|}{$\begin{array}{l}\text { Abbreviations: ARDS = acute respiratory distress syndrome; CRP = C-reactive protein; ICU = intensive care unit; Ig = immunoglobulin; OCB = oligoclonal band. } \\
\text { The remainder of the more severe neurologic symptoms (Miller-Fisher syndrome, polyneuritis cranialis, syncope, recrudescence, seizure, ataxia, } \\
\text { meningoencephalitis, hemorrhage, and possible demyelination) are listed in appendix e-1 (links.Iww.com/CPJ/A183). } \\
\text { e-References related to this article can be accessed at links.Iww.com/CPJ/A184. } \\
\text { a Anorexia was reported in } 55(39.9 \%) \text {, of which } 66.7 \% \text { required ICU care vs } 30.4 \% \text { non-ICU care. Nineteen patients with nausea and vomiting (13.7\%), without } \\
\text { the skew in distribution of those requiring ICU care vs non-ICU care. } \\
\text { b All had elevated prothrombin time, fibrinogen concentrations, D-dimer, IgA anticardiolipin antibody, and IgA/G anti- } \beta \text {-glycoprotein I antibodies, but not } \\
\text { lupus anticoagulant. The authors concluded that the multiple cerebral infarcts were related to secondary antiphospholipid syndrome, although all patients } \\
\text { were older and had conventional vascular risk factors, and other potential explanations (e.g., findings of atrial fibrillation or cerebral vasculitis) were not } \\
\text { reported. }\end{array}$} \\
\hline
\end{tabular}

nonspecific, found in many viral illnesses, and may or may not indicate CNS involvement.

For example, although robust evidence for anosmia and ageusia is lacking, the American Academy of Otolaryngology-Head and Neck Surgery has established a COVID-19 Anosmia Reporting Tool for Clinicians, ${ }^{\mathrm{e}-24}$ as data emerge. ${ }^{\mathrm{e}-25, \mathrm{e}-26}$ In contrast to low rates of anosmia and ageusia in hospitalized or critically ill patients, 2 retrospective studies of only patients with mild-tomoderate COVID-19 report high rates of olfactory and gustatory impairment of over $68 \%-80 \%{ }^{{ }^{e-1, e-2}}$ Although there may be substantial selection bias in the questionnaire response, these symptoms may be more prominent or more acknowledged in milder disease.

SARS-CoV-2 is associated with more serious neurologic complications including ischemic stroke, intracerebral hemorrhage, encephalopathy, Guillain-Barré syndrome, meningoencephalitis, syncope, seizures, possible demyelination, and recrudescence of prior strokes, seizure syndromes, or MS pseudorelapse (table 4).

In a series of 214 from Wuhan, China, $\sim 40 \%$ of patients had at least 1 comorbidity that increased the risk of stroke, such as hypertension, cardiovascular disease, diabetes, or cancer. Patients with stroke had higher D-dimer levels compared with both those with severe non-CNS symptoms and those with nonsevere CNS symptoms. Although milder neurologic symptoms occurred within 1-2 days of symptom onset, the mean onset of stroke and impaired consciousness was 8-10 days into the illness. ${ }^{\mathrm{e}-27}$ Other case series have reported stroke onset within $0-4$ days (table 4 ).

Among 13 patients with stroke in a Wuhan series, there were 3 small vessel, 5 large vessel, and 3 cardioembolic strokes, as well as 1 cerebral venous thrombosis and 1 hemorrhage. ${ }^{\mathrm{e}-28}$ This suggests that the mechanism of stroke is likely not specific to a particular pathophysiologic feature of the SARS-CoV-2 virus, but rather the result of nonspecific effects of inflammation, and endothelial and coagulation dysfunction, likely superimposed on preexisting risk factors.

Although systemic inflammation from infectious disease is a recognized stroke risk factor, as discussed above, large studies on other viruses such as influenza A show only a $1 \%$ incidence of stroke over a period of 45 days. ${ }^{\text {e- } 12}$ In acute respiratory distress syndrome (ARDS) intensive care 
patients, patients treated with standard-of-care mechanical ventilation (with referral to venovenous extracorporeal membrane oxygenation [ECMO] for refractory cases) developed only $5 \%$ ischemic stroke and $2 \%-4 \%$ hemorrhagic stroke events. ${ }^{\mathrm{e}-29}$

The causes of common neurologic symptoms in critical illness may include drug-induced paralysis, hypotension, ECMO, concomitant superinfections, profound changes in systemic thromboinflammation/immune cellular function, and extended immobility. Profound multiorgan involvement of COVID-19 may multiply intensive care issues contributing to delirium. ${ }^{\mathrm{e}-30}$ Of 113 deceased patients with COVID-19 in 1 series, 23 (20\%) had hypoxic encephalopathy. ${ }^{\text {e-31 }}$ Chinese brain autopsies show endovasculitis, endothelial damage, cerebral edema, hyperemia, and neurodegeneration with SARS-CoV-2 $2^{\mathrm{e}-32}$ - many of these findings could also be attributed to critical illness as discussed earlier. To understand the neurologic role of SARS-CoV-2 in critically ill patients with COVID-19, further data are needed on the frequency of neurologic complications of critical illness, such as thrombosis, critical illness myoneuropathy, and cerebral hypoperfusion. For example, the American Heart Association's Get With The Guidelines COVID-19 registry will add an urgent module designed to capture nation-wide data on the cardiovascular and neurologic effects of COVID-19. ${ }^{\mathrm{e}-33}$

\section{At-risk Neurologic Patients}

As suggested by coronavirus mechanisms of neurologic injury, there is potential for some neurologic patients to be at increased risk for further morbidity (table 5). Patients with preexisting $\mathrm{BBB}$ compromise may be at higher risk. Stroke-induced suppression of the innate and adaptive immune systems, mediated by dysregulation of the autonomic nervous system, is well described $^{\mathrm{e}-34}$ and may increase susceptibility to, and severity of, SARS-CoV-2 infection in the acute phase of stroke and therefore worsen clinical outcomes. Another potential risk of infection is the dementia-related behaviors that may make it difficult for patients to comply with key infection prevention measures (e.g., remembering to wash hands). ${ }^{\mathrm{e}-35}$

Given the susceptibility of patients with respiratory comorbidities to COVID-19, some neurologic patients may be more susceptible to COVID-19-related morbidity due to underlying respiratory compromise in preexisting neuromuscular disease, ${ }^{\mathrm{e}-36}$ major stroke, ${ }^{\mathrm{e}-18}$ and advanced neurodegeneration. For example, in hemispheric stroke, cough, expiratory muscle function and functional residual capacity are impaired. ${ }^{\mathrm{e}-37, e-38}$ Other neurologic patients with frequent cardiac comorbidities, such as patients with Parkinson disease, may also be at higher risk, although there is no evidence that Parkinson disease or other movement disorders decrease chance of survival when compared with otherwise similar patients. ${ }^{\mathrm{e}-39}$ As seen with other infections, patients with chronic deficits having COVID19 may have recrudescence or worsening of their neurologic symptoms, including seizure, MS pseudorelapse, or residua from stroke. ${ }^{\mathrm{e}-40}$
Table 5 COVID-19 Considerations for Specific Neurologic Patients

\begin{tabular}{ll}
\hline Preexisting neurologic condition & $\begin{array}{l}\text { Possible considerations to be } \\
\text { addressed }\end{array}$ \\
\hline Structural lesions & $\begin{array}{l}\text { Decreased seizure threshold, } \\
\text { recrudescence }\end{array}$ \\
\hline $\begin{array}{l}\text { Neuromuscular respiratory } \\
\text { weakness }\end{array}$ & $\begin{array}{l}\text { Worse outcome with COVID-19 } \\
\text { respiratory symptoms }\end{array}$ \\
\hline Myasthenia gravis & $\begin{array}{l}\text { Respiratory compromise with } \\
\text { contraindicated medications } \\
\text { (hydroxychloroquine/azithromycin) }\end{array}$ \\
\hline $\begin{array}{l}\text { Neuroinflammatory and } \\
\text { autoimmune disorders }\end{array}$ & $\begin{array}{l}\text { Discussions with patients about } \\
\text { immunomodulatory medications }\end{array}$ \\
\hline Acute stroke & $\begin{array}{l}\text { Hospital shortages limiting staffing/ } \\
\text { utilization of advanced } \\
\text { interventional mechanisms }\end{array}$ \\
\hline Dementia & $\begin{array}{l}\text { Reluctance to present urgently to } \\
\text { hospital during pandemic }\end{array}$ \\
\hline $\begin{array}{l}\text { Recognizing prothrombotic state of } \\
\text { Covid-19 }\end{array}$ \\
\hline $\begin{array}{l}\text { (e.g., difficulty following strict hand } \\
\text { hygiene) }\end{array}$ \\
\hline
\end{tabular}

Immunosuppressed patients have been specifically cautioned about COVID-19, ${ }^{\mathrm{e}-41}$ although clear data regarding their risk are not yet available. Clinicians and patients are already weighing these advisories when deciding on standard-of-care treatments; ${ }^{\mathrm{e}-42}$ the data remain controversial. ${ }^{\mathrm{e}-43-\mathrm{e}-46}$

Thromboembolic disease is common in COVID-19. Deep venous thrombosis was confirmed in $27 \%$ of 184 COVID-19 ICU patients (of which pulmonary embolism was $81 \%$ ), despite prophylaxis. ${ }^{\mathrm{e}-47}$ Traditional contraindications to anticoagulant therapy, such as a prolonged activated partial thromboplastin time (aPTT), may not be as helpful in patients with COVID-19 in whom prolonged aPTT and lupus anticoagulant may be seen. ${ }^{\mathrm{e}-48}$ Neurologists and intensivists will need to carefully weigh the benefits of antithrombotic therapies against the risks of intracerebral hemorrhage.

Although staging models of clinical COVID-19 disease progression warrant consideration of neurologic involvement, ${ }^{\mathrm{e}-49}$ the realities of sterilization and staffing of head imaging studies during a pandemic are restrictive and may limit neurologic investigations in patients with COVID-19 who have severe cardiopulmonary complications.

Finally, widespread social isolation policies may be restricting neurologic patient access to specialist care, with widespread closures of outpatient neurology offices. As the case fatality rate of COVID-19 for elderly patients with dementia is 3-11x that of patients in their $50 \mathrm{~s}$, ${ }^{\mathrm{e}-50}$ patients with dementia may 
be disproportionately affected by stringent restrictions aimed at protecting the highest COVID-19 risk group.

\section{Longer-term Neurologic Implications of COVID-19}

It remains unknown whether SARS-CoV-2 will cause longer-term neurologic morbidity. It is important to consider whether widespread recovered COVID-19 in our population will be a risk factor for other neurologic sequelae.

Psychiatric disease and fatigue may occur in severe COVID-19 survivors, as was reported after SARS. For example, 63\% of SARS survivors from a Hong Kong hospital responded to a survey a mean 41 months after recovery; over $40 \%$ had active psychiatric illness, $40 \%$ complained of chronic fatigue, and $27 \%$ met the 1994 diagnostic criteria for Chronic Fatigue Syndrome. In another small study of 22 SARS survivors who were unable to return to work mainly as health care workers, symptoms closely overlapped with chronic fibromyalgia (chronic fatigue, pain, weakness, depression, and sleep disturbance). ${ }^{13}$

Longer-term stroke risk factors may also be elevated after severe coronavirus infection. ${ }^{\text {e-22 }}$ For example, in a 12 -year follow-up study of 25 patients infected with SARS-CoV and treated with methylprednisolone vs 25 healthy controls (average age 47 years, body mass index $24 \mathrm{~kg} / \mathrm{m}^{2}$ ), $68 \%$ vs $40 \%$ reported hyperlipidemia, $60 \%$ vs $16 \%$ reported glucose metabolism disorder, and $44 \%$ vs $0 \%$ reported cardiovascular system abnormalities. ${ }^{\mathrm{e}-51}$ Mechanisms for these increased prevalences are uncertain.

Infection is a risk factor for decreased cognitive function, both acutely and over time. In addition, a dose response with severity of infection has been associated with accelerated cognitive decline. ${ }^{\mathrm{e}-52}$ Common infections such as upper respiratory tract infections, pneumonia, periodontal infections/inflammation, and general infections, particularly concurrent infections, are also associated with an increased risk of Alzheimer disease and related dementias. ${ }^{\mathrm{e}-53-\mathrm{e}-61}$ Sepsis survivors showed not only cognitive deficits in verbal learning and memory but had reduction of left hippocampal volume compared with healthy controls. ${ }^{\mathrm{e}-62}$ Seventy percent to $100 \%$ of ARDS survivors had cognitive impairment at discharge-46\%-80\% 1 year later-and worse impairment correlated with ARDS severity. ${ }^{\mathrm{e}-63}$ Cognitive and behavioral impairment after COVID-19 may warrant study.

Finally, ongoing and planned critical trials of neurodegenerative and non-life-threatening chronic neurologic disorders are being paused to keep elderly and vulnerable patients away from hospitals, which could have implications for those trials as well as advances in neurodegeneration research.

\section{Implications for Pediatric Neurology}

Implications for pediatric neurology remain very uncertain; just 2 case reports suggest COVID-19-associated paroxysmal events in infants (table 4). ${ }^{\mathrm{e}-64}$ Coronavirus $\mathrm{HCoV}-\mathrm{OC} 43$ was detected in the CSF of a child presenting with acute demyelinating encephalomyelitis. ${ }^{16}$ Although other pediatric viral infections were associated with a higher incidence of diseases such as MS, there is insufficient evidence to make the same assertion about coronaviruses. ${ }^{7,17, e-65}$ Rare neurologic complications of medium-vessel vasculitis have also occurred in the past, ${ }^{\mathrm{e}-66}$ and now a case of Kawasaki disease after COVID-19 has been reported. ${ }^{\mathrm{e}-67}$ Because the outcomes of COVID-19 seem to be more favorable in many children, it will be difficult to estimate the potential role of coronavirus infection in long-term pediatric neurologic health.

SARS-CoV-2 is associated with several neurologic symptoms and syndromes including headache, fatigue, anosmia, ageusia, anorexia, myalgias, asthenia, meningitis, Guillain-Barré syndrome, altered consciousness, syncope, and stroke. Understanding the potential neurologic implications of COVID-19, and lessons from previous experience with coronaviruses, will help neurologists and others recognize and intervene in neurologic morbidity during and after the pandemic of 2020. It is difficult to fully separate the direct neurologic effects of COVID-19 from the secondary neurologic complications of critical systemic illness, but both issues need to be considered, given the overwhelming spread of COVID-19.

\section{Acknowledgment}

The authors thank Dr. Richard Mayeux for his helpful review of a draft of this manuscript.

\section{Study Funding}

Anna S. Nordvig is supported by NINDS 5T32 NS007153 (PI Elkind) and the Charles and Ann Lee Brown Fellowship. Kiran T. Thakur is supported by NIH 1K23NS105935-01. Amelia K. Boehme is supported by NINDS NIH R03 NS101417 and NINDS NIMHD R21 MD012451. Craig J. Smith is supported by the University of Manchester and Salford Royal NHS Foundation Trust and has received funding from the NIHR, MRC, and the Leducq Foundation. Mitchell Elkind is supported by the National Institute of Neurological Disorders and Stroke and the Leducq Foundation. The content is solely the responsibility of the authors and does not necessarily represent the official views of the sponsoring institutions.

\section{Disclosure}

The authors report no disclosures relevant to the manuscript. Full disclosure form information provided by the authors is available with the full text of this article at Neurology.org/cp.

\section{Publication History}

Received by Neurology: Clinical Practice April 16, 2020. Accepted in final form June 12, 2020. 
$\rightarrow$ Diverse neurologic manifestations and long-term neuropsychiatric sequelae have been reported in infections with numerous previously known coronaviruses.

$\rightarrow$ Potential neurologic complications of COVID-19 include headache, fatigue, dizziness, anosmia, ageusia, anorexia, myalgias, meningoencephalitis, hemorrhage, altered consciousness, Guillain-Barré syndrome, syncope, seizure, and stroke.

$\rightarrow$ Mechanisms of neurologic disease may be similar to other coronaviruses, especially to SARS-CoV, which is phylogenetically most similar and enters cells through the same protein, angiotensin-converting enzyme 2.

\section{$\rightarrow$ Postulated mechanisms of neurologic damage from other coronaviruses suggest the possibility of} systemic disease sequelae (including inflammation, thrombosis, and hypoxia), direct neuroinvasiveness (although neurotropism has never been definitively shown), peripheral nervous system and muscle involvement, and possible immune-mediated paraand postinfectious effects.

$\rightarrow$ In neurologic patients, special consideration is needed for compliance with hygiene and social distancing, COVID-19 symptom identification, stroke management, and comorbidity management.

\begin{tabular}{lll}
\hline Name & Location & Contribution \\
\hline $\begin{array}{l}\text { Wendy S. Vargas, } \\
\text { MD }\end{array}$ & $\begin{array}{l}\text { Columbia University, The } \\
\text { New York Presbyterian } \\
\text { Hospital }\end{array}$ & $\begin{array}{l}\text { Interpreted the data and } \\
\text { revised the manuscript } \\
\text { for intellectual content }\end{array}$ \\
\hline $\begin{array}{l}\text { Craig J. Smith, } \\
\text { MBChB, MD, MRCP }\end{array}$ & $\begin{array}{l}\text { University of Manchester, } \\
\text { United Kingdom }\end{array}$ & $\begin{array}{l}\text { Interpreted the data and } \\
\text { revised the manuscript } \\
\text { for intellectual content }\end{array}$ \\
\hline $\begin{array}{l}\text { Mitchell S.V. } \\
\text { Elkind, MD, MS }\end{array}$ & $\begin{array}{l}\text { Columbia University, The } \\
\text { New York Presbyterian } \\
\text { Hospital }\end{array}$ & $\begin{array}{l}\text { Provided supervision and } \\
\text { funding; interpreted the } \\
\text { data; and major role in } \\
\text { revising the manuscript } \\
\text { for intellectual content }\end{array}$ \\
& &
\end{tabular}

\section{References}

1. World Health Organization. WHO Director-General's opening remarks at the media briefing on COVID-19-March 11, 2020

2. Johns Hopkins University \& Medicine Coronavirus Resource Center [online]. Available at: https://coronavirus.jhu.edu/map.html. Accessed July 16, 2020.

3. Ferguson N, Laydon D, Nedjati Gilani G, et al. Report 9: Impact of nonpharmaceutical interventions (NPIs) to reduce COVID19 mortality and healthcare demand. 2020.

4. Zhu N, Zhang D, Wang W, et al. A novel coronavirus from patients with pneumonia in China, 2019. N Engl J Med 2020;382:727-733.

5. Desforges M, Le Coupanec A, Dubeau P, et al. Human coronaviruses and other respiratory viruses: underestimated opportunistic pathogens of the central nervous system? Viruses 2020;12:14.

6. Arbour N, Day R, Newcombe J, Talbot PJ. Neuroinvasion by human respiratory coronaviruses. J Virol 2000;74:8913-8921.

7. Principi N, Bosis S, Esposito S. Effects of coronavirus infections in children. Emerg Infect Dis 2010;16:183.

8. Morfopoulou S, Brown JR, Davies EG, et al. Human coronavirus OC43 associated with fatal encephalitis. N Engl J Med 2016;375:497-498.

9. Lu R, Zhao X, Li J, et al. Genomic characterisation and epidemiology of 2019 novel coronavirus: implications for virus origins and receptor binding. Lancet 2020;395: 565-574.

10. Elliott R, Li F, Dragomir I, Chua MMW, Gregory BD, Weiss SR. Analysis of the hos transcriptome from demyelinating spinal cord of murine coronavirus-infected mice. PLoS One 2013;8:e75346.

11. Tsai L, Hsieh S, Chang Y. Neurological manifestations in severe acute respiratory syndrome. Acta Neurol Taiwan 2005;14:113.

12. Lau KK, Yu WC, Chu CM, Lau ST, Sheng B, Yuen KY. Possible central nervous system infection by SARS coronavirus. Emerg Infect Dis 2004;10:342.

13. Moldofsky H, Patcai J. Chronic widespread musculoskeletal pain, fatigue, depression and disordered sleep in chronic post-SARS syndrome; a case-controlled study. BMC Neurol 2011;11:37.

14. Hung EC, Chim SS, Chan PK, et al. Detection of SARS coronavirus RNA in the cerebrospinal fluid of a patient with severe acute respiratory syndrome. Clin Chem 2003;49:2108-2109.

\section{Appendix Authors}

\begin{tabular}{lll}
\hline Name & Location & Contribution \\
\hline $\begin{array}{lll}\text { Anna S. Nordvig, } \\
\text { MD }\end{array}$ & $\begin{array}{l}\text { Columbia University, The } \\
\text { New York Presbyterian } \\
\text { Hospital }\end{array}$ & $\begin{array}{l}\text { Designed and } \\
\text { conceptualized the } \\
\text { article; interpreted the } \\
\text { data; and drafted the } \\
\text { manuscript for } \\
\end{array}$ \\
& $\begin{array}{l}\text { intellectual content } \\
\end{array}$
\end{tabular}

\begin{tabular}{ll}
\hline Kathryn T. Fong, & Columbia University, The \\
MD & New York Presbyterian \\
& Hospital
\end{tabular}

Interpreted the data and significant role in revising the manuscript for intellectual content

\begin{tabular}{lll}
\hline $\begin{array}{l}\text { Joshua Z. Willey, } \\
\text { MD, MS }\end{array}$ & $\begin{array}{l}\text { Columbia University, The } \\
\text { New York Presbyterian } \\
\text { Hospital }\end{array}$ & $\begin{array}{l}\text { Interpreted the data and } \\
\text { revised the manuscript } \\
\text { for intellectual content }\end{array}$ \\
\hline $\begin{array}{l}\text { Kiran T. Thakur, } \\
\text { MD }\end{array}$ & $\begin{array}{l}\text { Columbia University, The } \\
\text { New York Presbyterian } \\
\text { Hospital }\end{array}$ & $\begin{array}{l}\text { Interpreted the data and } \\
\text { revised the manuscript } \\
\text { for intellectual content }\end{array}$ \\
\hline $\begin{array}{l}\text { Amelia K. Boehme, } \\
\text { PhD, MSPH }\end{array}$ & $\begin{array}{l}\text { Columbia University, The } \\
\text { New York Presbyterian } \\
\text { Hospital }\end{array}$ & $\begin{array}{l}\text { Interpreted the data and } \\
\text { revised the manuscript } \\
\text { for intellectual content }\end{array}$ \\
& &
\end{tabular}

15. Bohmwald K, Galvez N, Ríos M, Kalergis AM. Neurologic alterations due to respiratory virus infections. Front Cell Neurosci 2018;12:386.

16. Yeh EA, Collins A, Cohen ME, Duffner PK, Faden $\mathrm{H}$. Detection of coronavirus in the central nervous system of a child with acute disseminated encephalomyelitis. Pediatrics 2004;113:e73-e76.

17. $\mathrm{Li} \mathrm{Y}, \mathrm{Li} \mathrm{H}, \mathrm{Fan} \mathrm{R}$, et al. Coronavirus infections in the central nervous system and respiratory tract show distinct features in hospitalized children. Intervirology 2016;59: $163-169$.

18. Xu J, Zhong S, Liu J, et al. Detection of severe acute respiratory syndrome coronavirus in the brain: potential role of the chemokine mig in pathogenesis. Clin Infect Dis 2005;41:1089-1096.

19. Steardo L, Zorec R, Verkhratsky A. Neuroinfection may potentially contribute to pathophysiology and clinical manifestations of COVID-19. Acta Physiol (Oxf) 2020; 229:e13473.

20. Le Coupanec A, Desforges M, Meessen-Pinard M, et al. Cleavage of a neuroinvasive human respiratory virus spike glycoprotein by proprotein convertases modulates neurovirulence and virus spread within the central nervous system. PLoS Pathog 2015; 11:e1005261.

21. Desforges M, Le Coupanec A, Brison É, Meessen-Pinard M, Talbot PJ. Neuroinvasive and neurotropic human respiratory coronaviruses: potential neurovirulent agents in humans. In: Adhikari R, Thapa S, eds. Infectious Diseases and Nanomedicine I. India: Springer; 2014:75-96.

22. Huang C, Wang Y, Li X, et al. Clinical features of patients infected with 2019 novel coronavirus in Wuhan, China. Lancet 2020;395:497-506.

23. Netland J, Meyerholz DK, Moore S, Cassell M, Perlman S. Severe acute respiratory syndrome coronavirus infection causes neuronal death in the absence of encephalitis in mice transgenic for human ACE2. J Virol 2008;82:7264-7275.

24. Doobay MF, Talman LS, Obr TD, Tian X, Davisson RL, Lazartigues E. Differential expression of neuronal ACE2 in transgenic mice with overexpression of the brain reninangiotensin system. Am J Physiol Regul Integr Comp Physiol 2007;292:R373-R381. 
25. Gowrisankar YV, Clark MA. Angiotensin II regulation of angiotensin-converting enzymes in spontaneously hypertensive rat primary astrocyte cultures. J Neurochem 2016;138:74-85.

26. Xia H, Lazartigues E. Angiotensin-converting enzyme 2: central regulator for cardiovascular function. Curr Hypertens Rep 2010;12:170-175.

27. MacGregor DP, Murone C, Song K, Allen AM, Paxinos G, Mendelsohn FA. Angiotensin II receptor subtypes in the human central nervous system. Brain Res 1995;675:231-240.

28. Xia $\mathrm{H}$, Lazartigues $\mathrm{E}$. Angiotensin-converting enzyme 2 in the brain: properties and future directions. J Neurochem 2008;107:1482-1494.

29. Lovren F, Pan Y, Quan A, et al. Angiotensin converting enzyme-2 confers endothelial protection and attenuates atherosclerosis. Am J Physiol Heart Circ Physiol 2008;295: H1377-H1384.

30. Biancardi VC, Stern JE. Compromised blood-brain barrier permeability. J Physiol 2016;594:1591-1600.

31. Varatharaj A, Galea I. The blood-brain barrier in systemic inflammation. Brain Behavior Immun 2017;60:1-12

32. Li YC, Bai WZ, Hashikawa T. The neuroinvasive potential of SARS-CoV2 may be at least partially responsible for the respiratory failure of COVID-19 patients. J Med Virol 2020;92:552-555.
33. McCray PB, Pewe L, Wohlford-Lenane C, et al. Lethal infection of K18-hACE2 mice infected with severe acute respiratory syndrome coronavirus. J Virol 2007;81:813-821.

34. Li K, Wohlford-Lenane C, Perlman S, et al. Middle East respiratory syndrome coronavirus causes multiple organ damage and lethal disease in mice transgenic for human dipeptidyl peptidase 4. J Infect Dis 2016;213:712-722.

35. Tsai LK, Hsieh ST, Chao CC, et al. Neuromuscular disorders in severe acute respiratory syndrome. Arch Neurol 2004;61:1669-1673.

36. Chao CC, Tsai LK, Chiou YH, et al. Peripheral nerve disease in SARS: report of a case. Neurolgy 2003;61:1820-1821.

37. Ding $\mathrm{Y}$, Wang $\mathrm{H}$, Shen $\mathrm{H}$, et al. The clinical pathology of severe acute respiratory syndrome (SARS): a report from China. J Pathol 2003;200:282-289.

38. Gu J, Gong E, Zhang B, et al. Multiple organ infection and the pathogenesis of SARS. J Exp Med 2005;202:415-424.

39. Rahaman P, Del Bigio MR. Histology of brain trauma and hypoxia-ischemia. Acad Forensic Pathol 2018;8:539-554.

40. Perlman S, Evans G, Afifi A. Effect of olfactory bulb ablation on spread of a neurotropic coronavirus into the mouse brain. J Exp Med 1990;172:1127.

(References e-1 to e-108 available at: links.lww.com/CPJ/A184.) 


\title{
Neurology ${ }^{\circ}$ Clinical Practice
}

\author{
Potential Neurologic Manifestations of COVID-19 \\ Anna S. Nordvig, Kathryn T. Fong, Joshua Z. Willey, et al. \\ Neurol Clin Pract 2021;11; e135-e146 Published Online before print June 30, 2020 \\ DOI 10.1212/CPJ.0000000000000897
}

This information is current as of June 30, 2020

\begin{abstract}
Updated Information \&
Services

including high resolution figures, can be found at:

http://cp.neurology.org/content/11/2/e135.full.html

References

This article cites 36 articles, 7 of which you can access for free at: http://cp.neurology.org/content/11/2/e135.full.html\#\#ref-list-1

Citations

This article has been cited by 2 HighWire-hosted articles:

http://cp.neurology.org/content/11/2/e135.full.html\#\#otherarticles

Subspecialty Collections

This article, along with others on similar topics, appears in the following collection(s):

All Cerebrovascular disease/Stroke

http://cp.neurology.org//cgi/collection/all_cerebrovascular_disease_str oke

COVID-19

http://cp.neurology.org//cgi/collection/covid_19

Public health

http://cp.neurology.org//cgi/collection/public_health

Viral infections

http://cp.neurology.org//cgi/collection/viral_infections

Permissions \& Licensing

Information about reproducing this article in parts (figures,tables) or in its entirety can be found online at:

http://cp.neurology.org/misc/about.xhtml\#permissions

Reprints

Information about ordering reprints can be found online:

http://cp.neurology.org/misc/addir.xhtml\#reprintsus
\end{abstract}

Neurol Clin Pract is an official journal of the American Academy of Neurology. Published continuously since 2011, it is now a bimonthly with 6 issues per year. Copyright ( 2020 American Academy of Neurology. All rights reserved. Print ISSN: 2163-0402. Online ISSN: 2163-0933.

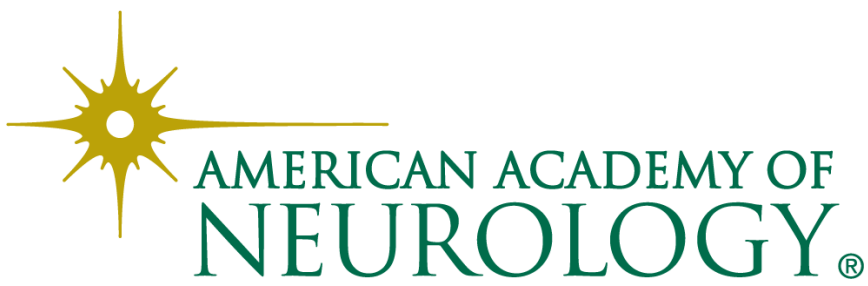

